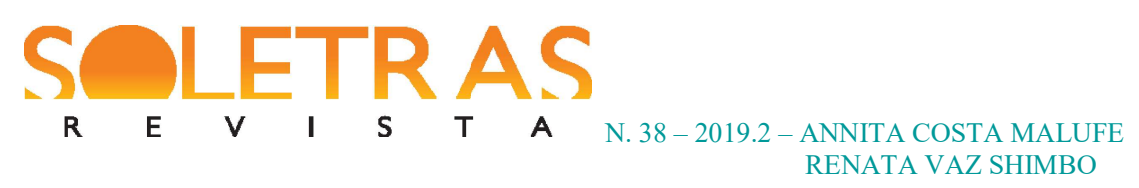

\title{
Deslocamentos contínuos: territórios e línguas em Samuel Beckett
}

\author{
Annita Costa Malufe ${ }^{1}$ \\ Renata Vaz Shimbo ${ }^{2}$
}

\begin{abstract}
Resumo: O artigo enfoca a questão do trabalho de escrita com a língua estrangeira, e suas consequências literárias, na produção de Samuel Beckett (1906-1989), escritor e dramaturgo irlandês que optou por viver na França e escrever em francês, deslocando-se de sua língua e pátria natais, tendo mais tarde passado a se autotraduzir, propondo um trânsito constante entre o inglês e o francês. Partindo dos conceitos de território e desterritorialização, propostos pela filosofia de Gilles Deleuze e Félix Guattari, o artigo visa apontar para três principais desterritorializações que seriam responsáveis por uma poética do deslocamento e da errância constantes, que caracterizaria a obra de Beckett: desterritorialização do país de origem, da língua natal e, por fim, da linguagem verbal como um todo. O objetivo é acompanhar as linhas de deslocamento que levam suas obras, em especial as de sua prosa final, a criar uma língua singular que, paulatinamente, terá como potência a desestabilização da própria dinâmica da linguagem enquanto sistema de representação.
\end{abstract}

Palavras-chave: Samuel Beckett. Desterritorialização. Deslocamento. Deleuze e Guattari.

\section{Deslocar, desterritorializar}

Quando questionado sobre a opção por adotar o francês em sua escrita literária, Samuel Beckett, escritor e dramaturgo irlandês, afirmou que se tratava de uma língua na qual poderia "empobrecer-se mais. Este foi o verdadeiro motivo." (apud BIRKENHAUER, 1976, p.110). O autor, cuja língua nativa era o inglês, estabeleceu-se definitivamente na França, em Paris, a partir de 1937, onde viveu até sua morte, em 1989.

Beckett foi, além de um escritor que escreveu em uma língua alheia à sua, também aquele a forjar sua própria língua; ato de criação que advém de um processo que Gilles Deleuze, a partir de Michel Proust, referiu-se, em diversos momentos de sua obra, como o empreendimento dos grandes escritores (dentre os quais incluía Beckett): a criação de uma língua estrangeira na própria língua natal. Processo em que: “a língua deixa escapar uma

\footnotetext{
${ }^{1}$ Professora do Programa de Estudos Pós-Graduados em Literatura e Crítica Literária da PUC-SP; Pesquisadora CNPq (bolsa produtividade), SP, Brasil.E-mail: annitacostamalufe@gmail.com. (i) https://orcid.org/ 0000-00026843-197X

${ }^{2}$ Doutoranda no Programa de Estudos Pós-Graduados em Literatura e Crítica Literária da PUC-SP,_SP, Brasil. E-mail: revshimbo@gmail.com. (i) https://orcid.org/0000-0002-4050-7960
} 


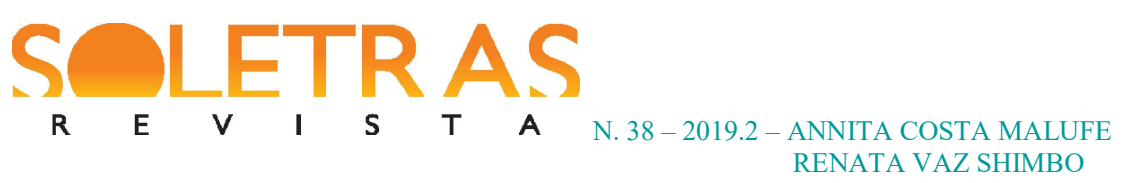

língua estrangeira desconhecida, para atingir os limites da linguagem” (DELEUZE, 2011, p.129). Podemos notar que a criação sintática marca desde o início a produção de Beckett, mas intensifica-se quando o escritor opta pelo francês. Em todo caso, os efeitos da escrita beckettiana são, além do já conhecido hibridismo de gêneros que ronda sua produção, uma escrita de difícil apreensão, fugidia, alheia à representação e que opera em um campo tão poético quanto prosódico, transcendendo os limites da arte, sobretudo na última fase de sua obra. Uma ruptura com um território chamado língua - ou, para usar os termos de Gilles Deleuze e Félix Guattari (2003), aquele da "língua maior”, a língua instituída, normativa.

Assim, podemos afirmar que há um processo de contínuos deslocamentos em Beckett, que se inicia em uma mudança física de país, passa por uma transição de idioma, ou um “exílio linguístico" (ANDRADE, 2001, p.31), e culmina em uma operação de questionamento e desconstrução da própria linguagem escrita. São três momentos significativos de quebras, descontinuidades, em sua produção, responsáveis por saltos que poderíamos denominar por importantes desterritorializações, se tivermos em vista o conceito de Deleuze e Guattari desenvolvidono platô “Acerca do ritornelo”, de Mil platôs (1997).

A necessidade de aqui propormos tais deslocamentos enquanto "desterritorializações" deve-se à proposta de se considerar, no caso beckettiano, o sentido amplo de um deslocamento espaço-temporal que extrapola dimensões empíricas, compreendendo saltos qualitativos entre as relações implicadas em cada campo novo constituído: o novo país não é somente um novo lugar; assim também a língua não é apenas um idioma a ser aprendido, mas são novos eixos que forçam a criação de novas relações, inusitadas, das quais emerge a necessidade de criar novas conexões na escrita. A desterritorialização que vai mais longe, em Beckett, neste sentido, será aquela da própria linguagem, que se verá abalada em suas bases, de sistema de representação aparentemente fixo, estável, em equilíbrio, como veremos a seguir.

Vale ressaltar ainda, de modo a explicitar as bases conceituais de nosso artigo, que o território, tal como proposto em Mil platôs, é a resultante de um processo, sempre inacabado, de constituição de um campo de forças, a partir de uma dinâmica de relações que se dá no ritornelo (conceito proposto pelos filósofos, a partir de uma noção musical) - esta, sempre marcada por três etapas, aspectos, ou momentos concomitantes: 1. eleger um centro; 2. girar 


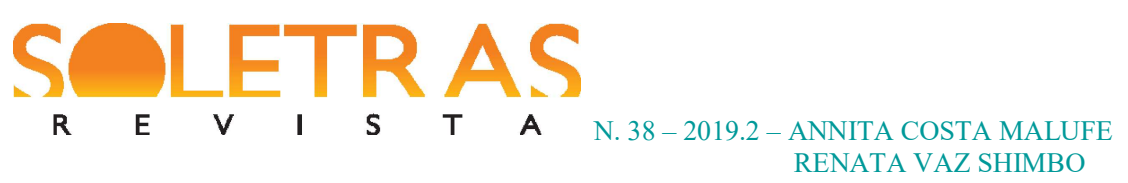

em torno dele; 3. escapar desse centro em direção a um outro centro - para então recomeçar (DELEUZE; GUATTARI, 1997, p.117). O ritornelo implica, portanto, em um movimento contínuo de repetição da diferença $;^{3}$ dele, resulta a dinâmica de constituição do território, enquanto ato, primordialmente rítmico, que territorializa os elementos do ritornelo, ou seja, cria um lugar dessas relações entre os elementos aí tomados.O que marca um território é não somente os elementos que nele se agregam, mas as velocidades, lentas ou aceleradas, contínuas ou interrompidas, das relações entre eles: suas constâncias e andamentos, suas pausas e retomadas, seus escapes; há um ritmo das relações e é ele que marca o território, que dá a ele um tom e uma singularidade. Até o ponto em que esses movimentos vão derivando tanto que iniciam um novo território: de repente sentimos já não estar no mesmo lugar, a atmosfera mudou, o tom se alterou, o território anterior se desfez e um novo se insinua.

Pensado dessa forma, o território é não somente móvel, como constituído por um movimento, perpétuo, de aproximação, distanciamento e fuga de um determinado centro; eleição de novo centro, em que um novo território se fará, e assim por diante. Ele é a resultante de formas de relação, e não um ponto localizável e material, somente. Neste sentido, uma língua pode constituir um território, bem como formações subjetivas constituem territórios existenciais; do mesmo modo que um texto apresenta a dinâmica de criação e desfazimento de territórios; e que a arte lida, principalmente, com a territorialização e a desterritorialização, criando e escapando de lugares que são espaços-tempo para além do "local" empírico e material. Deleuze e Guattari propõem-nos o ritornelo para pensar um processo que remeteria a todos os corpos, sejam animais, vegetais ou mesmo cósmicos; apontando-nos para um modo ampliado de se pensar tanto a arte quanto a cultura.

Notemos ainda que no movimento de territorialização, implicado no ritornelo, parte-se do impulso de se criar uma casa em meio à ausência de formas: o estabelecimento de um centro, um eixo, em meio ao caos; um lugar seguro, em que um determinado corpo reconhece como seu e, consequentemente, se autorreconhece enquanto habitante desse lugar. Um animal e seus hábitos, uma criança que canta para se acalmar - a canção de ninar ou mesmo as

\footnotetext{
${ }^{3}$ Nos limites deste artigo, não seria possível expor esta que é a principal tese desenvolvida por Deleuze, desde Diferença e repetição (1968), uma de suas principais obras; assinalamos somente a relação do ritornelo com o movimento de repetir o diferente, que está na base de sua filosofia da diferença, comprometida com o pensamento do devir, implicando assim em uma nova concepção do tempo e do sentido.
} 


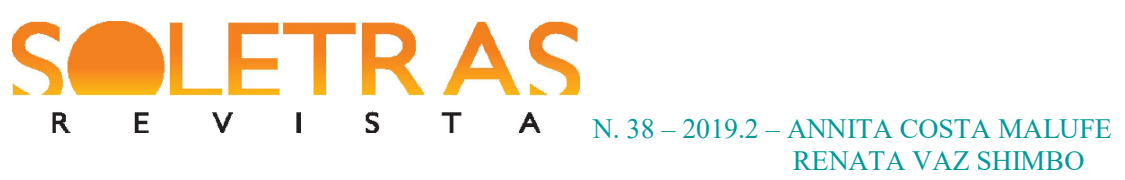

histórias contadas às crianças antes de dormir ocupam essa função territorializante (DELEUZE; GUATTARI, 1997, p.116). A arte então começa com a casa - é o que Deleuze e Guattari dirão em $O$ que é a filosofia?(1992, p.240), mas também, com outras palavras, em Mil platôs, ao descreverem adinâmica dos territórios enquanto campos de relação, com seus contornos e suas redes internas de trocas em seus ritmos singulares.

É nesses termos que, no presente artigo, é nosso intuito apontar as três principais desterritorializações que seriam responsáveis por uma poética do deslocamento e da errância que, a nosso ver, caracterizaria profundamente a obra de Beckett: desterritorialização do país de origem, da língua natal e, por fim, da linguagem verbal como um todo.

\section{Dar voz a uma língua estrangeira}

A primeira fase dos escritos de Beckett, produzida em meados da década de 1930, em inglês, caracteriza-se por uma escrita de modernismo heroico, na qual privilegia efeitos paródicos e opta pela presença de um clássico narrador em terceira pessoa. É o caso de Dream of fair to middling women (1932), sua primeira novela, publicada apenas postumamente, More pricks than kicks (1934), que foi um fracasso de venda editorial quando publicado pela primeira vez, ou Murphy (1938), por exemplo.

Beckett, neste momento, escreve apenas em inglês e se vale de um discurso no qual a própria realidade denuncia o caráter falsificador da linguagem. Não há um enredo fundamentado em grandes saltos narrativos, o que acabará por ser uma característica de toda prosa beckettiana que se segue. Em "Dante and the lobster", a primeira das histórias curtas que compunha a coletânea More pricks than kicks, tem-se a narração do que seria um conto clássico, mas com as típicas distorções características do autor, pois a presença de um personagem preguiçoso e indolente nos surge como uma zombaria ao romance tradicional, de personagens motivados e grande narrativa. Ao mesmo tempo, surge um narrador desinflado, em terceira pessoa, com poucas interferências, contando-nos sobre um personagem metódico que tem três tarefas a cumprir em seu dia: comer, buscar uma encomenda no peixeiro e assistir a uma aula de italiano. O título nos remete ao grande escritor italiano para, em 


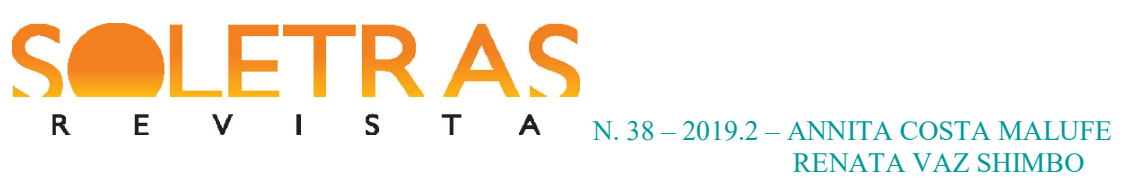

seguida, trazer-nos uma narrativa que burla aquilo que é potente e luminoso e faz surgir uma prosa sobre o hábito, com descrições hiper-realistas e o que de menos criativo há no homem. Caso também de uma peça como Éleuthéria (1947) que, ainda que escrita anos depois, é mais marcada por uma crítica presente nos conteúdos dos diálogos do que propriamente no questionamento da forma do texto que, em si, permanece mais tradicional.

Entretanto, vale assinalar que, já nesta primeira fase, seus personagens se manifestam como sujeitos em trânsito por um deslocamento compulsório, isto é, estão sempre se deslocando, seja porque, mesmo no lugar, sentem-se deslocados e fora de contexto, seja porque foram expulsos ou por estarem indo embora de algum lugar. Personagens no caminho, porém, não a caminho de algum lugar. Muitas vezes sem saber de onde e para onde, o personagem beckettiano é marcado por uma não-identidade fragmentada, sem memória, e por um corpo que lhe serve de carcaça (ANDRADE, 2001, p.33), o que mais tarde culminará na ruptura da membrana que diferencia a realidade exterior com seu mundo interno.

Será entre os anos de 1945 e 1946, que o autor inaugura uma nova fase em sua prosa, ao iniciar a escrita na nova língua, o francês, através de quatro novelas: Premier Amour, L'expulsé, Le calmant e La fin. É dessa época também a peça que tornará o autor célebre: Em attendant Godot [Esperando Godot], de 1948, escrita primeiramente em francês, e apesar de escrita pouco tempo depois, já bem distante da retórica do drama burguês que ainda subsiste em Éleuthéria.

Nos escritos desta etapa, em que incluiríamos ainda a trilogia beckettiana do pósguerra, composta por Molloy (1951), Malone Meurt (1951) e L'innommable (1953), é possível perceber o abandono do modernismo clássico novecentista, a partir de quando se inicia o processo de hibridismo de gêneros em sua obra, ou trânsito entre os gêneros. No caso do romance, há um movimento de renovação, na intenção de que ele se reinvente. Alguns veem nisso a denúncia de uma impossibilidade de narrar, após a Segunda Grande Guerra e a incontornável experiência de fragmentação que teria levado o gênero romance a seu termo. Fato é que, sobretudo no último volume da trilogia, procedimentos que sustentam o romance tradicional tornam-se inoperantes, em especial os temas (adultério, jovem do campo, fracasso amoroso), assim como a recusa do que pode haver de idílico no amor e no sexo. O ciclo de otimismo do sujeito burguês não mais se justifica e os elementos de que depende o romance 


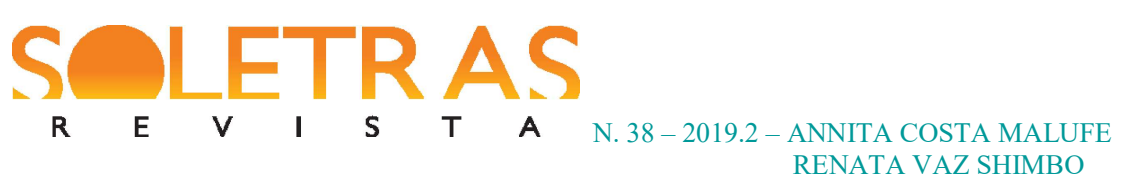

tradicional para ramificar-se, como traumas, memórias e as próprias histórias, são aplastados por um enredo rarefeito e personagens que não conseguem morrer, ao mesmo tempo em que não possuem qualquer desenvolvimento psicológico.

Os narradores beckettianos em primeira pessoa, narradores narrados, trazem personagens que expressam a crise do sujeito burguês através dos dejetos do que sobra da sociedade burguesa por meio da denúncia do esvaziamento. A maioria deles sem nome, apresentam uma indiferença em relação ao mundo, ao próprio leitor e à sua história, como o narrador de $O$ expulso, que encerra a novela com: "Não sei por que contei essa história. Poderia muito bem ter contado outra. Talvez outra hora poderei contar outra. Almas vivas, verão que elas se parecem.” (BECKETT, 2006, p.24). Outra característica que desponta neste momento é um acúmulo de fatos no enredo que não se justifica pelo encadeamento, ou seja, não há peripécias ou novidades individuais, assim como tampouco se manifesta o progresso do tempo, mas muito mais uma aparente entropia. Os personagens não sofrem consequências para suas ações, pois se inicia um processo no qual a relação de enunciação da mensagem se dá mais com a própria mensagem do que com a experiência. Não há uma história a ser contada, mas tampouco cessa a necessidade obsessiva de narrar: "no silêncio não se sabe, é preciso continuar, não posso continuar, vou continuar.” (BECKETT, 2009, p.185), dizem as últimas palavras da voz que fala em $O$ Inominável, narrativa após a qual Beckett disse ter chegado a um de seus maiores impasses criativos, próximo ao nada - "the next next to nothing", na expressão de Beckett em uma carta. ${ }^{4}$

Em $O$ inominável, Maurice Blanchot ressalta a presença da uma "fala errante", sem centro, sem começo ou fim, que já não é a fala de um sujeito, mas é o próprio curso de uma linguagem que "se" fala incessantemente, numa "obsessão impessoal" (1959, p.286). Um murmúrio incessante sem nome e sem dono que daria a ouvir a própria materialidade da língua. O narrador beckettiano torna-se um "moinho de palavras", conforme Rachel Boué, na esteira de Blanchot; essa voz é tomada por uma fala sem fim, que dá a ouvir o murmúrio incessante da língua, inominável, anônimo (BOUÉ, 2009, p.51). Trata-se de um fluxo ininterrupto de palavras que "destrona a supremacia do sentido" (BOUÉ, 2009, p.57), que rompe a camada da significação e a lógica narrativa, afirmando a língua em sua presença de

\footnotetext{
${ }^{4}$ Carta a Leventhal, datada de 03/02/1953 (cf. KNOWLSON, 1996, p.461).
} 


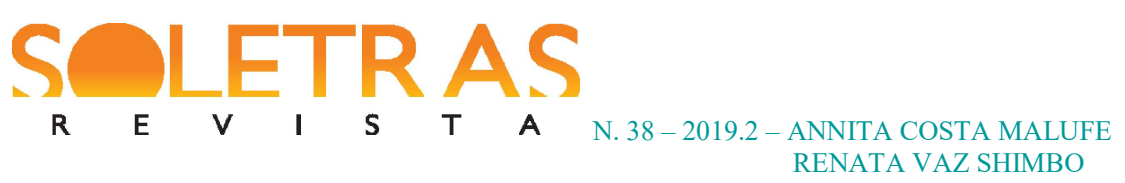

plástica e sonora. No prefácio à tradução brasileira desse quase romance, ou romance às avessas, João Aldolfo Hansen chamará atenção justamente à dissolução do sujeito, à qual corresponde a ausência de um corpo onde a voz se ancorar, e vice-versa: "A eliminação da representação unitária do corpo equivale à ausência de instâncias válidas de subjetivação que é acusada pela voz.” (HANSEN, 2009, p.13)

Convém mencionar que, antes disso, o próprio Beckett manifestava seu incômodo em escrever em inglês, em uma conhecida carta de 1937, a chamada carta alemã, a seu amigo Axel Kaun. Já aí ele demonstra enxergar os limites de seu idioma, ou os limites de se escrever em um idioma por demais conhecido, natal: como se aí as associações figurativas da linguagem e seu caráter representativo fossem mais difíceis de serem quebrados e combatidos. E todo edifício retórico parecia já não bastar para significar o que gostaria de dizer:

\begin{abstract}
Está se tornando mais e mais difícil, até sem sentido, para mim, escrever em um inglês oficial. E, mais e mais, minha própria língua me parece como um véu que precisa ser rasgado para chegar às coisas (ou ao Nada) por trás dele. Gramática e estilo. Para mim, eles parecem ter se tornado tão irrelevantes quanto o traje vitoriano ou a imperturbabilidade do verdadeiro cavalheiro. Uma máscara. Tomara que chegue o tempo, graças a Deus que em certas rodas já chegou, em que a linguagem é mais eficientemente empregada quando mal empregada. (BECKETT apud. ANDRADE, 2001, p.167)
\end{abstract}

Para Beckett, a única maneira de expressar-se a contento seria falhar com a língua, levá-la à desgraça, inaugurando uma escrita da despalavra, na qual a linguagem se encontra em um constante confronto entre significar e des-significar, produzindo imagens fugidias, que se diluem conforme se desenham. Sua intenção, neste momento, era desnudar as acepções que a visão historicizada da língua carrega para, através de fendas, criar procedimentos capazes de produzir novas imagens ou significados, ou seja, o esgotamento dos sentidos pré-existentes na linguagem, de seu dizer bem, dos clichês, para, a partir destes buracos, alcançar a liberdade de dizer o não dito, o inominável da palavra, o subjetivo, as experiências, livre das amarras das aderências da significação.

Tal engendramento não ocorre, no entanto, por meio de um uso arbitrário da linguagem, que abandonaria qualquer linha sintática ou gramatical, mas através de uma de suas variações ramificadas, torcendo a sintaxe e a reinventando. Existe um sistema sintático 


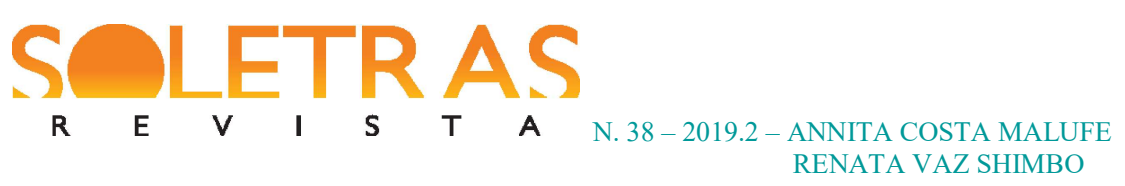

formal em devir, porém, verifica-se uma criação em vias de nascer, como se de fato uma língua estrangeira se formasse, o que Deleuze chama de: "uma criação de sintaxe que faz nascer uma língua estrangeira na língua, uma gramática do desequilíbrio" (DELEUZE, 2011, p.144) e nomeia como o ato de gaguejar.

Beckett conseguiria fazer a língua "gaguejar", sobretudo em seus últimos textos, alguns mencionados por Deleuze nesse seu artigo de Crítica e clínica. A potência criadora da gagueira (pensada aqui como uma estratégia literária), para o filósofo, estaria em um modo específico de se utilizar o recurso da repetição, fazendo com que as palavras surjam como que nascidas de um abalo sísmico, que desestabiliza a estrutura da língua enquanto sistema homogêneo e em equilíbrio. “Quando a língua está tão tensionada a ponto de gaguejar ou de murmurar, balbuciar..., a linguagem inteira atinge o limite que desenha o seu fora e se confronta com o silêncio.” (DELEUZE, 2011, p.145). É neste ponto, segundo Deleuze, que os grandes escritores desafiam o estilo e deixam escapar novas criações desatadas das amarras da língua normativa.

Dialogando com essa ideia de Deleuze, diríamos que, a partir de quando opta pelo francês, Beckett lança mão de estratégias de escrita que mais e mais se valem da repetição, sustentando um tempo lento, que se estica e põe cada vez mais em suspensão a ação. Crise da ação e crise do tempo, como diagnosticará mais tarde Hand-Thies Lehmann (2007), tendo a dramaturgia de Beckett como um ponto fulcral do que definirá como teatro pós-dramático. As palavras, expressões ou orações se repetem exaustivamente, rodam em círculos como que buscando a si mesmas. É o fluxo contínuo de palavras de $O$ inominável, dessa voz que busca a si mesma e escapa. São os tiques dos personagens de Esperando Godot, em seu girar eterno em torno de um centro ausente, retomando argumentos e orações vazias, na imagem que Hugh Kenner (1968) cria de que Vladimir e Estragon trazem a corda bamba para perto do chão e caem. Há uma verdadeira suspensão da ação, uma não-ação, o que Robbe-Grillet observou como uma quebra da noção tradicional do drama que Beckett expressaria exemplarmente com seus personagens "irremediavelmente presentes", sem passado nem futuro, em um aqui-agora imóvel (ROBBE-GRILLET, 1963 p.103). Imobilidade esta que se fará mais e mais presente. Enquanto o personagem de Molloy anda pelo mundo, Malone está preso a uma cama e em $O$ inominável não há sequer um corpo. 


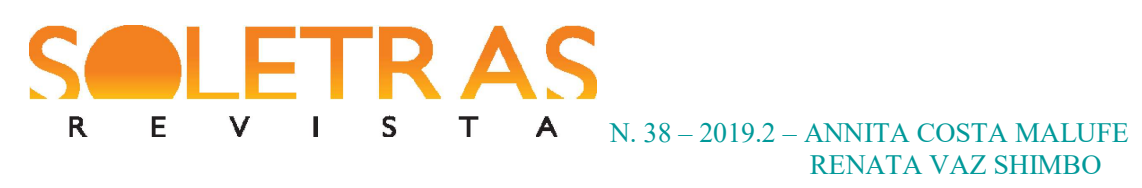

Neste sentido, a adoção do francês por Beckett parece ter sido fundamental para que ele se libertasse de hábitos territoriais infiltrados na língua e pudesse, junto a isso, lançar-se a descobertas que seriam fundamentais para toda uma nova dramaturgia e literatura. Tal escolha teria sido, ao menos no início, um modo de "reduzir o espectro de suas possibilidades linguísticas" (CHESTIER, 2003, p. 149), empobrecer-se mais, conforme vimos, acima, na fala do próprio Beckett. O novo idioma desfaz as relações com a tradição da língua inglesa e o coloca em uma posição de sujeito que ocupa um extrato marginal completo, ou seja, um olhar estranho, alheio, ainda que interno, uma vez que se trata de um idioma que domina, mas um olhar sempre um pouco deslocado. Conforme aponta Alain Chestier, a opção pela língua francesa seria uma garantia para se conseguir exprimir o drama da linguagem, da cesura entre as palavras e as coisas - e cita a fala de Beckett: "Em francês é mais fácil escrever sem estilo" (CHESTIER, 2003, p. 148).

Será na nova língua que surgirá, também, uma nova camada de significação de humor em Beckett, que se manifesta através de obscenidades nos textos, mais marcadas nesta segunda fase, em francês, do que na primeira, em inglês. Ruby Cohn (1962) atribui esta característica ao fato de que seria na primeira infância que os tabus linguísticos são estabelecidos e, portanto, não operariam em uma segunda língua, que Beckett, ainda que jovem, aprendeu apenas depois de adulto. Neste sentido, vemos que a nova língua desprenderia também sua história, seu passado e as morais aí aprendidas, impregnadas no inglês.

Outro aspecto que temos em conta ao analisar a mudança linguística de Beckett e sua predileção por escrever em francês é o declarado antinacionalismo do escritor, que sempre lamentou o provincianismo irlandês, ao mesmo tempo em que não se identificava com o imperialismo britânico. A língua inglesa, para Beckett, era também a própria representação de um conflito identitário, sobretudo após a Segunda Guerra Mundial. José Francisco Fernández, na introdução de sua tradução para o espanhol de Premier amour, remete a este tema ao afirmar que:

O sentimento crítico sobre seu país se acresceu mais na época em que escreveu o relato (Premier amour), imediatamente depois da Segunda Guerra Mundial. Na opinião de muitos, incluindo o próprio Beckett, a 


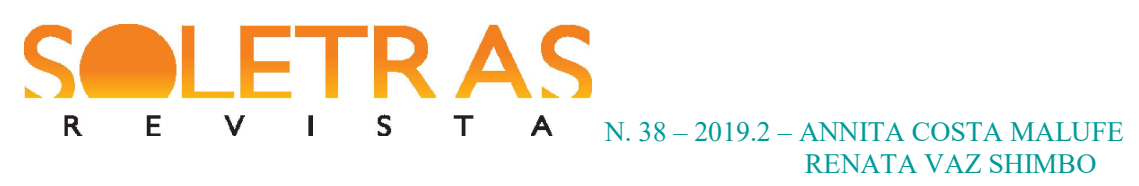

neutralidade de seu país durante o conflito chocava-o com um tipo de dilema moral frente o qual não era possível ficar à margem. (FERNÁNDEZ, 2017, p.14 - tradução nossa) $)^{5}$

Fato é que existe um afastamento emocional de Beckett em relação ao seu país que o coloca em uma posição marginal e sem pátria, deslocado, convertendo este sentimento em uma necessidade de deslocar a própria língua inglesa, de fazê-la torcer e sofrer abalos, o que se revela, ainda, nos processos de autotradução do autor. No caso de Premier amour, ao traduzi-lo ao inglês, o autor incluiu gírias e expressões que se falam nas ruas da Irlanda, distanciando cada vez mais daquela que seria a língua maior, sobre a qual Deleuze e Guattari se debruçam ao tratar da escrita de Franz Kafka, mas sobre a qual também podemos nos valer aqui. Para os filósofos, a chamada literatura menor é aquela que se empenha em subverter uma língua maior, canônica, provocando sua desterritorialização. É uma literatura que sonha um novo povo, que é feita por uma minoria, que não é dona da língua do poder. Kafka, um judeu tcheco, escrevendo em alemão; Beckett, irlandês, escrevendo em francês. Trata-se de escrever em uma língua estrangeira, mas também minorar a própria língua maior, a partir de procedimentos que abalam suas convenções e estabilidades. O menor aqui não remete a uma avaliação qualitativa, mas a uma condição que, marginal, possibilita a instauração de um novo fazer literário, "Ser em sua própria língua como um estrangeiro." (2003, p.54). Em Crítica e clínica, Deleuze retomará esta operação como o ato de: “inventar um uso menor da língua maior na qual se expressam inteiramente; eles (os escritores) minoram essa língua, como em música, onde o modo menor designa combinações dinâmicas em perpétuo desequilíbrio." (DELEUZE, 2011, p.141).

Esse desequilíbrio, provocado, às vezes, por uma gagueira - um dos modos de minorar a língua -, liberta as palavras para encontrarem novas relações, constituindo novas sintaxes, não previstas no uso corrente, e acostumado, dos nativos de cada língua. As palavras passam não só a gaguejar como a deslizar umas sobre as outras, friccionando novas imagens e desfazendo relações exigidas entre significante e significado. Daí a eloquente crise da

\footnotetext{
5 "El sentimiento crítico hacia su país se acrecentó más si cabe en la época en la que escribió el relato, inmediatamente después de la Segunda Guerra Mundial. En la opinión de muchos, incluido el propio Beckett, la neutralidad de su pais durante el conflicto chocaba con un tipo de dilema moral frente al que no era posible quedarse al margen."
} 


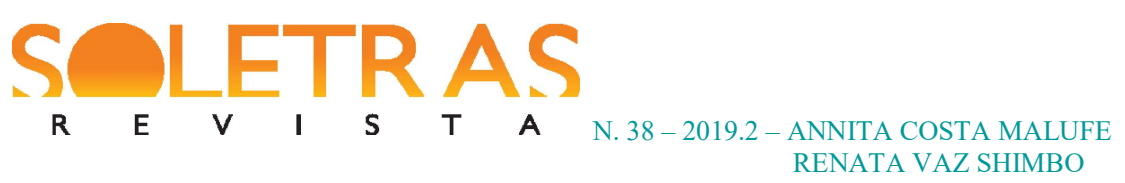

significação que permeará, em especial, a prosa beckettiana da última fase, considerada por muitos excessivamente hermética.

\section{Criar uma nova língua}

Novas estratégias de escrita surgirão nas obras posteriores à primeira trilogia. Comment c'est (1961) [Como é] trará uma prosa sem pontuação, composta por blocos de texto em lugar de parágrafos, separados entre si pelo espaço de uma linha. O fluxo contínuo da voz anônima agora é cortado em inúmeros momentos, e parece demarcado como uma partitura, em que a voz deixa a pontuação, as entonações, por conta da execução do leitor. Ponto importante de mais um estilo nascente na língua beckettiana, Comment c'est parece antecipar a língua escassa e sincopada da prosa final, ao "despedaçar o corpo da língua", como define Evelyne Grossman (2004, p.71), também no dispositivo de espacialização gráfica do texto.

A adoção do novo idioma é marcada pelo empobrecimento do vocabulário e a escassez sintática. Neste momento, acentuam-se procedimentos de linguagem que o autor adota com o novo idioma e que marcarão a última fase da segunda trilogia, da década de 1980. E, assim como seus personagens e narradores, a própria linguagem parece paulatinamente desmilinguir-se. Conforme vimos, tais estratégias estão longe de ser um gesto ingênuo; constituem uma operação voluntária de empregar mal a nova língua, de "cavar nela (na língua) um buraco atrás do outro, de maneira a acolher alguma coisa que vem de fora ou de algum outro lugar." (Apud ANDRADE, 2001, p.169), conforme a já citada carta alemã, de 1937. Como afirma Chestier: "O caso de Beckett, sem ser único, é raro: e aquele de um autor que escolheu deliberadamente empobrecer, descartando as tradições e renunciando às possibilidades oferecidas pelas diversas modalidades da expressão" (CHESTIER, 2003, p. 150).

Em seu ensaio L'Épuisé, Deleuze encontra em Beckett a presença de três línguas. Ainda que em uma leitura um tanto cronológica, pois há ênfase em uma linha de desenvolvimento de certos aspectos da escrita beckettiana, Deleuze dirá que a chamada Língua I seria aquela dada pela representação, a língua dos nomes e dos significados, presente 


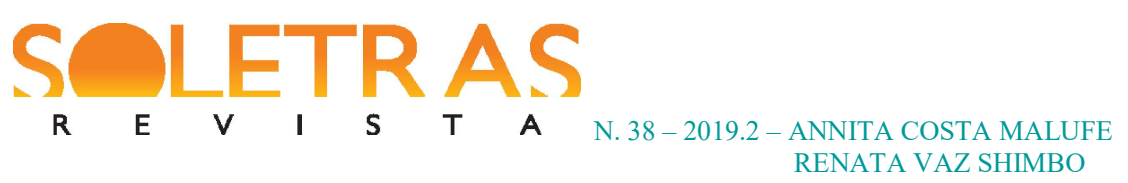

nos primeiros romances. Já a Língua II, a das vozes, da fala de um Outro que se manifesta, seria aquela da trilogia do pós-guerra, de que $O$ inominável é emblemático. Por fim, ao cruzar o limite da Língua III, Beckett finalmente teria alcançado a ruptura com a significação e criado uma língua capaz de produzir imagens que, exaurindo a linguagem, opera no surgimento de uma imagem alheia ao caráter mimético que estaria impregnado nas palavras, uma imagem de outra natureza, que irrompe desta operação: "Este algo visto, ou escutado, chama-se Imagem, visual ou sonora, desde que liberada das cadeias em que as duas outras línguas a mantêm.” (DELEUZE, 2010, p.8). As últimas obras seriam as que lançam mão dessa terceira língua, por exemplo, a trilogia formada por Company (1980), Mal vu mal dit (1981) e Worstward ho (1983). Mas Deleuze já enxerga em Comment c'est a operação dessa Língua III, a das imagens, em que visões e audições se produzem independentemente da camada de representação da palavra. Seria aqui que, para ele, Beckett chegaria à criação de uma língua que abalaria a base da própria linguagem, conforme dizíamos acima acerca da tripla desterritorialização operada por Beckett.

Neste ponto, a operação com esta Língua III transpassaria os limites da leitura e da palavra escrita para esgarçar o campo de significações. Há uma força criadora de imagens que se atualizam a cada leitura no corpo daquele que lê por meio de sons, ritmos, cores, disparadores de sentido por detrás daquilo que é lido, tornando essa escrita mais e mais performática, convocadora do corpo do leitor.

A terceira fase da escrita beckettiana, onde está inserida sua prosa final, caracteriza-se pela manifestação da ineficiência da linguagem e uma enunciação experimental, assim como um narrador experimental, ou a última pessoa narrativa. Não se trata da ausência de um narrador, mas da presença de um observador que não se denomina mais por um $e u$, mas que se afiança pelo olhar de um Outro, leitor, que garante sua existência. Em Worstward ho, por exemplo, já não há a presença de qualquer enredo, mas uma prosa estranha que, assim como manifestações da escrita contemporânea, escapa a qualquer classificação por gêneros. Neste texto, em que predominam as elipses, paronomásias e trocadilhos, percebemos a condução da leitura pelo som, em um ritmo extremamente singular. Enquanto em Mal vu mal dit ainda existia uma representação externa e o leitor era convidado a percorrer o labirinto do manicômio do crânio, em Worstward ho Beckett parece suprimir qualquer representação 


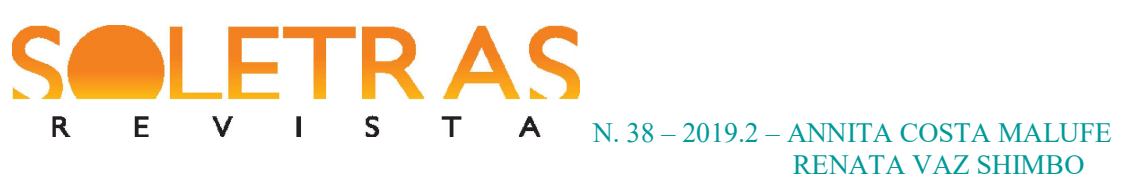

exterior e se instaura em um ato interno de imaginação, conforme podemos observar no trecho: "They fade. Now the one. Now the twain. Now both. Fade back. Now the one. Now the twain. Now both. Fade? No. Sudden go. Sudden back. Now the one. Now the twain. Now both." (BECKETT, 1983, p.14). ${ }^{6}$

A necessidade de dizer mal, neste momento, se acentua em um movimento de autocorreções no próprio texto, no qual surgem duplas negativas que, ao contrário de se afirmarem, revogam-se, como em: "Whose words? Ask in vain. Or not in vain if say no knowing. No saying. No words for him whose words. Him? One. No words for one whose words. One? It. No words for it whose words. Better worse so." (BECKETT, 1983, p.20). ${ }^{7}$ O que notamos são pares de palavras que se assemelham na sonoridade, mas com significados distantes na tentativa de encontrar um espaço em que não se possa piorar. Existe uma diferença entre o texto lido e aquele ouvido ou lido em voz alta. Trata-se de uma escrita de vazios e da figuração de imagens em desaparecem e constroem uma anatomia confusa e particular. A presença de quantificadores e intensificadores se radicaliza em respostas emocionais que alargam o território das possibilidades de expressão em um equilíbrio sempre dinâmico que tende ao movimento e não se esgota. Assim, esta nova linguagem permite a este corpo (estranho) que é lacunar, ausente, evanescente, que vai e volta, se coloque também em posições estranhas.

É possível enxergarmos nesta última fase uma ruptura radicalizada com as camadas representativas da linguagem, momento em que os processos de ressignificação ou dessignificação surgem como forças mais aparentes em seus textos. A língua, neste ponto de sua escrita, esgarça-se aos limites do reconhecimento e o mundo já não se resigna a ser nomeado pela linguagem. É aqui que o deslocamento se intensifica, a língua perde seus pontos de apoio e seus territórios mais estáveis.

Neste momento final de sua escrita, a linguagem é o espaço onde a percepção e a manifestação do mundo se resolvem de maneira concreta, porém traiçoeira, pois os traços

\footnotetext{
${ }^{6}$ Para as referências a Worstward ho, utilizaremos a tradução de Ana Helena Souza, em Companhia e outros textos (2012), com o título "Pra frente o pior". Nestes casos, referenciaremos apenas as páginas. "Desaparecem. Ora o um. Ora o par. Ora os dois. Reaparecem. Ora o um. Ora o par. Ora os dois. Desaparecem? Não. Súbita volta. Ora o um. Ora o par. Ora os dois." (p.69)

7 "Palavras de quem? Palavras em vão. Ou não em vão se dizer não se sabe. Não se diz. Sem palavras para ele cujas palavras. Ele? Um. Sem palavras para um cujas palavras. Um? Isso. Sem palavras para isso cujas palavras. Melhor pior assim." (p.74)
} 


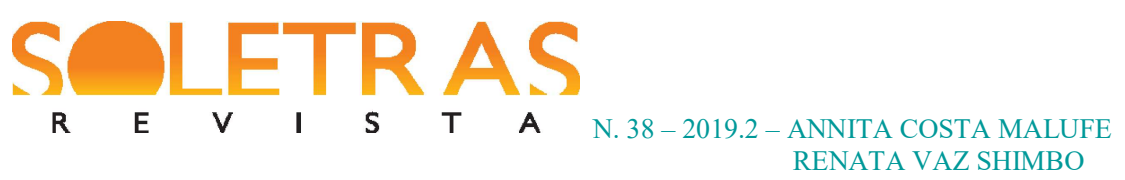

construídos, tão logo surgem, são borrados ou apagados. Não há um enredo constituído por ações ou personagens com desenvolvimento, mas criações de imagens que se repetem e ressurgem diferentes de quando haviam desaparecido.

Cada vez com mais intensidade, o tempo do texto beckettiano coincide com o tempo do acontecimento da linguagem, ou seja, se faz na leitura e no encontro entre a narração e o efeito daquilo que esta linguagem produz, os movimentos que constituem a leitura se criam em processos muito velozes e por vezes abruptos. No lugar do tempo do enredo, do representado, sobressai-se o tempo o tempo da performance, próximo ao que dirá Lehmann sobre o novo teatro, em que em lugar de se representar o tempo tem-se: "o processo de apresentação em sua própria temporalidade” (LEHMANN, 2007, p.297). Em Beckett, o leitor está constantemente exposto a experiências limítrofes e radicais de procedimentos de uma arte povera em vias de desaparecer e ressurgir inesperadamente. A própria condição temporal não é uma marca segura, pois o tempo não é dado como um movimento de enredo, mas um tempo que se deposita sem sucessões e que emerge corporalmente na execução do texto.

Escritos em inglês, Company e Worstward ho marcam seu retorno à língua-mãe, sendo que, significativamente, Beckett não traduz o último para o francês. De suas obras mais importantes, foi a única que Beckett optou por não autotraduzir e, quando questionado, afirmou não haver encontrado, no francês, correspondência possível para a tradução sem que a força das palavras se perdesse. O que notamos neste texto é uma ferida no léxico e na correspondência com a referencialidade, extremando-se as dificuldades da linguagem. A insuficiência da linguagem é empurrada para um extremo de esgarçar seu uso ao pior possível, destruindo-a pelo excesso e alargando o espaço das possibilidades de expressão. Fracassar, fazer falhar a representação, tal o lema beckettiano. Para encontrar o novo lugar onde tudo que foi dito é empurrado para a gaveta do pior, é preciso encontrar um novo, dramatizado ao extremo, contra a natureza inercial, extravasar, estragar tudo pelo excesso: "Next two. From bad to worsen. Try worsen. From merely bad. Add -. Add? Never." (BECKETT, 1983, p.25). ${ }^{8}$ O pior está no centro do que só assume sua verdadeira identidade

\footnotetext{
8“Próximos dois. De mau para piorar. Tentar piorar. De meramente mau. Acrescentar -. Acrescentar? Nunca." (p.74)
} 


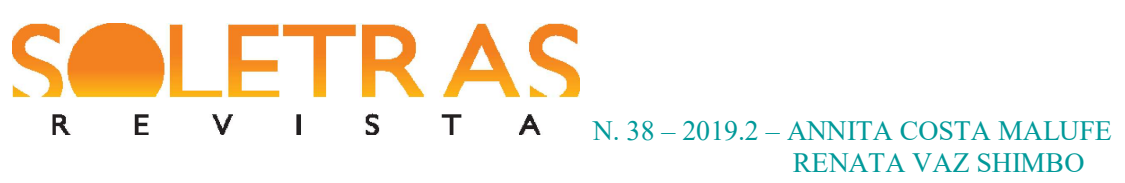

quando encontra sua forma de ser mal dito, em torno de um imperativo único, ou seja, não é por acréscimo que se procede. Alargar ou somar nunca, mas apenas dizer.

Não há, em Beckett, um território seguro no qual se avalizar uma presença, mas sim uma movimentação inusitada e um inconstante jogo de retomadas e repetições, tanto internas quanto entre as próprias obras. Trata-se de remissões de farrapos de memória, retomadas de obras anteriores, fiapos de outros ditos, filiações elípticas que compõem um grande território em constante movimento, pois matizado de outros muitos que se criam, fogem, diluem e recriam.

Tampouco seria seguro falar-se em um "estilo" de Beckett, uma vez que há um deslocamento contínuo. Evelyne Grossman defende que haveria "as escritas", no plural, de Beckett, indicando com isso a instabilidade de uma assinatura ou daquilo que reconhecemos como estilo de um autor, algo identitário. Para ela Beckett criaria: "Uma língua sem estilo, uma língua se desfigurando em movimento incessante" (2004, p.52). Portanto, a língua de Beckett estaria em um movimento sem pausa, marcado por torções e desequilíbrios que a impedem de se fixar em forma ou figuras (de estilo ou retórica).

O leitor desavisado, ao buscar em Beckett o apoio da referencialidade, se frustrará ao deparar-se com uma língua que mais se serve da função rítmica a favor da poeticidade para alcançar um fluxo disparador de sensações e imagens. Neste ponto, é preciso, de fato, aceitar a perda do que seriam os limites de um território seguro para inaugurar uma nova constituição espacial e temporal, na maior parte do tempo vivida em círculos de repetições.

Ao considerarmos a língua como uma marca de território, temos em Beckett a ruptura com esta territorialização, processo este que já se fazia presente em seus primeiros escritos, quando não expressava uma mimese da narrativa tradicional, mas, ao contrário, a própria reconstituição de uma ordem sem significados, tendo em conta a linguagem sempre como um pano de fundo para representar o mundo. Contudo, este processo se acentua com a mudança de país e, sobretudo, com a escolha do francês, em especial na terceira fase de sua escrita, através de sua prosa final. Ligar-se ao francês seria, portanto, uma forma de despojar-se da tradição literária advinda do inglês, desterritorializar-se, conforme ressalta George Steiner como "uma estratégia de permanente exílio" (STEINER, 1990, p.27). Steiner compara Beckett a Borges e Nabokov, unindo-os na genialidade dos modernistas da década de 50, ao 


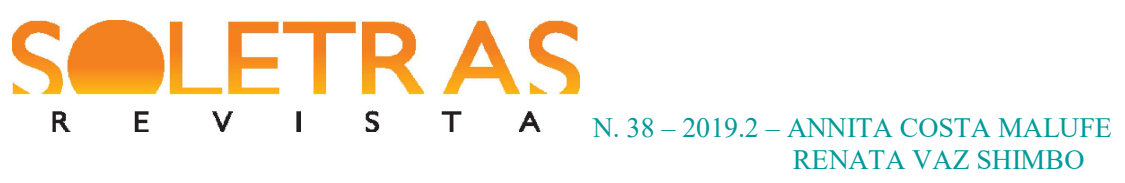

analisar que os escritores deste período seriam "turistas incessantes olhando as vitrines de todo o âmbito das formas disponíveis." (STEINER, 1990, p.27).

Neste sentido, parece-nos que a fala de Steiner corrobora com nossa intenção de apontar que Beckett reforça o conceito de desterritorialização de Deleuze e Guattari em três processos que se refletem em sua escrita, sendo o primeiro deles aquele que se refere ao seu não pertencimento à própria pátria, o que o levou a imigrar da Irlanda para a França até sua morte. O segundo deles, sua adoção ao francês como sua língua de escrita, sem, contudo, abandonar por completo o inglês através das autotraduções que, mais que um mero processo de traduzir os próprios escritos, como vimos, refletia-se em uma reescrita dos originais, incorporando neles elementos de um inglês irlandês que reforçava o caráter marginal de sua escrita. Por fim, e para isto nos ativemos mais à sua prosa final, verificamos, à luz de Deleuze, a criação de uma língua própria, na qual nos parece que Beckett, sobretudo em Worstward ho, ter finalmente alcançado a expressão através da insuficiência das palavras e inaugurado uma nova escritura.

\section{Referências}

ANDRADE, Fábio de Souza. Samuel Beckett: o silêncio possível. São Paulo: Ateliê, 2001.

BECKETT, Samuel. Malone meurt. Paris: Minuit, 1951. . Molloy. Paris: Minuit, 1951.

. L'Innommable. Paris: Minuit, 1953.

. More pricks than kicks. Nova York: Groove press, 1970

. Premier amour. Paris: Minuit, 1970.

. Poèmes, suivi de Mirlitonnades. Paris: Minuit, 1978.

. Mal vu mal dit. Paris: Minuit, 1981.

. Worstward ho. New York: Groove Press, 1983.

. Collected shorter plays. New York: Grove Press, 1984. 


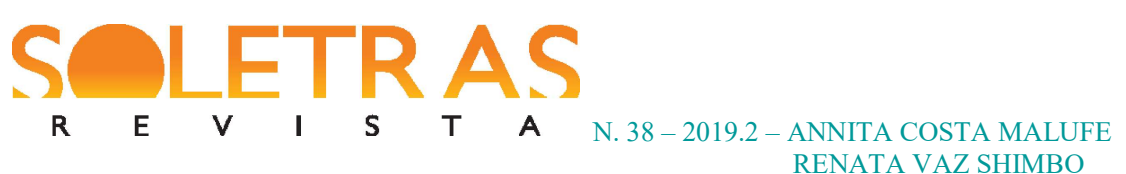

\section{. Compagnie. Paris : Minuit, 1985.}

$\overline{1983)}$.

Cap au pire. Trad. Edith Fournier. Paris: Minuit, 1991 (do original Worstward Ho,

. Como é. Trad. Ana Helena Souza. São Paulo: Iluminuras, 2003 (dos originais em francês Comment c'est, 1961, e em inglês How is it, 1964).

. O expulso. In: Novelas. Trad. Eloisa Araújo Ribeiro. São Paulo: Martins Fontes, 2006.

. O Inominável. Trad.: Ana Helena Souza. São Paulo: Editora Globo, 2009.

. Pour finir encore et autres foirades . Paris: Minuit, 1976, 1991, 2001, 2004.

. Companhia e outros textos. Trad. Ana Helena Souza. São Paulo: Globo, 2012.

. Pra frente o pior. In: .Companhia e outros textos. Trad. Ana Helena Souza. São

Paulo: Globo, 2012.

. Primer amor. Trad. José Francisco Fernández. Almería: Edual, 2017.

BIRKENHAUER, Klaus. Samuel Beckett. Madrid: Alianza Editorial, 1976.

BLANCHOT, Maurice. Le Livre à venir. Paris: Gallimard, 1959.

BOUÉ, Rachel. L'Éloquence du silence. Paris: L'Harmattan, 2009.

CHESTIER, Alain. La Littérature du silence-Essai sur Mallarmé, Camus et Beckett. Paris: L'Harmattan, 2003.

COHN, Ruby. The comic gamut. New Brunswick: Rutgers University Press, 1962.

DELEUZE, Gilles. Crítica e clínica. Trad. Peter Pál Pelbart. São Paulo: Editora 34, 2011.

. Différence et répétition. Paris : P.U.F., 1968.

. O Esgotado. In: Sobre o teatro: um manifesto de menos. Trad. Roberto Machado. São Paulo: Zahar, 2010.

DELEUZE, Gilles; GUATTARI, Félix. Kafka: para uma literatura menor. Trad. Rafael Godinho. Lisboa: Assírio \& Alvim, 2003.

. Mil platôs - vol.4. Trad. Suely Rolnik. São Paulo: Editora 34, 1997. 


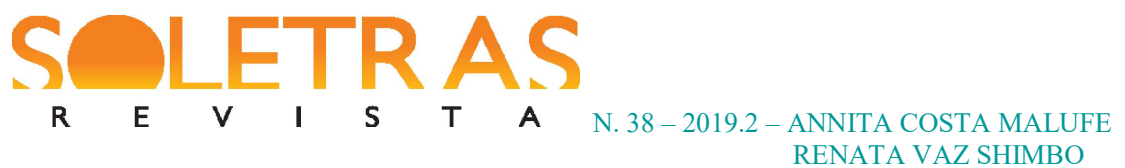

. O que é a filosofia? Trad. Bento Prado Jr. E Alberto Alonso Muñoz. São Paulo: Editora 34, 1992.

GROSSMAN, Evelyne. La défiguration-Artaud-Beckett-Michaux. Paris: Minuit, 2004.

HANSEN, João Adolfo. Eu nos faltará sempre (Prefácio). In: BECKETT, Samuel. $O$ inominável. Tradução: Ana Helena Souza. São Paulo: Globo, 2009.

KENNER, Hugh. Samuel Beckett: a critical study. California: University of California Press, 1968.

KNOWLSON, James. Damned to fame: the life of Samuel Beckett. London: Bloomsbury, 1996.

LEHMANN, Hans-Thies. Teatro pós-dramático. Trad. Pedro Süssekind. São Paulo: Cosac Naify, 2007.

ROBBE-GRILLET, Alain. Pour un nouveau roman. Paris: Minuit, 1963.

STEINER, George. Extraterritorial. A literatura e a revolução da linguagem. Trad. Julio Castañon Guimarães. São Paulo: Companhia das Letras, 1990.

\title{
Continuous displacements: territories and languages in Samuel Beckett
}

\begin{abstract}
The article focuses on the question of writing in a foreign language, and its literary consequences, in Samuel Beckett's production (1906-1989). Irish writer and playwright, Beckett chose to live in France and write in French, shifting from his native language and homeland, later opting to self-translate, proposing a constant traffic between English and French. Starting from the concepts of territory and deterritorialization, proposed by Gilles Deleuze and Félix Guattari's philosophy, this article points to three mains deterritorializations; process responsible for Beckett's poetics of a constant displacement: deterritorialization of origin country, of native language and, finally, of the language as a whole. Our objective is to show the displacement lines which take his works, especially those of the last phase, towards a creation of a singular language which, gradually, will destabilize language dynamics of representation.
\end{abstract}

Keywords: Samuel Beckett. Deterritorialization. Displacement. Deleuze and Guattari.

Recebido em: 14 de junho e 2019.

Aceito em: 12 de agosto de 2019. 